\title{
crítica de exposición
}

\author{
Transtextualidad y Burla en la pintura de Francisco \\ Peinado. La ruta del oro. Galería JM (Málaga).Del 02- \\ 10-09 hasta 21-11-09
}

Emilio Chavarría

A Rafael Alvarado.

Desde el momento que atravesamos la puerta de la galería o del museo para ver una exposición de Francisco Peinado, irremediablemente nos encontramos con el lenguaje visual propio y original de este artista, el cual viene utilizando desde hace ya bastante tiempo y que no es extraño para aquellos que conozcan su trayectoria pictórica, al que podríamos llamar, para entendernos, una escritura personal o lenguaje que contiene en sí su gramática y su retórica, por lo que es posible leer sus textos sin tener que salirse fuera de ellos; es decir, sin buscar una interpretación o un discurso que se halle más allá o detrás de los mismos aunque lleve el nombre o la pose de estética, pues lo único que se puede encontrar queriendo salir fuera-deltexto es nada; no hay nada detrás o más allá de las obras, pero esta nada hay que entenderla en todo caso en el sentido de algo: la inmensidad espacial del vacío o la eternidad temporal de la soledad; esto es lo que podemos encontrar detrás si nos empeñamos en buscar ahí: nada, vacío y soledad, pues todo lo demás lo tenemos, como siempre, delante de nuestras propias narices, si se me permite la ruda expresión. Así, el sentido se halla contenido en el propio texto pictórico, en la materialidad de la propia cadena narrativa y textual de las obras. Todas sus imágenes están inscritas dentro de un sistema interno de significantes textuales determinado y en el juego de sus diferencias y alteraciones, por eso es preciso prestar atención a lo que el propio texto nos muestra: una historia, gramática y retórica textual propia, que podemos incluir dentro de la categoría estética o figura retórica de la parodia y su lógica textual: intertextualidad, cita, imitación, estilización o transformación de géneros, en este caso populares. Una imitación y transposición estilística con función lúdica, crítica o ridiculizadora bastante explícita. A su vez, como toda parodia es en cierta medida una especie de homenaje a los géneros parodiados, en las obras de esta exposición podemos suponer el aprecio del artista por estos géneros de la fantasía popular e infantil que el séptimo arte ha llevado a la pantalla.

El propio título de la exposición, La ruta del oro, nos traslada desde el principio al mundo del imaginario colectivo de las películas del oeste, lo que se confirma en cuanto vemos algunas de sus obras, repletas de su exuberante temática más tópi- 


\section{crítica de exposición}
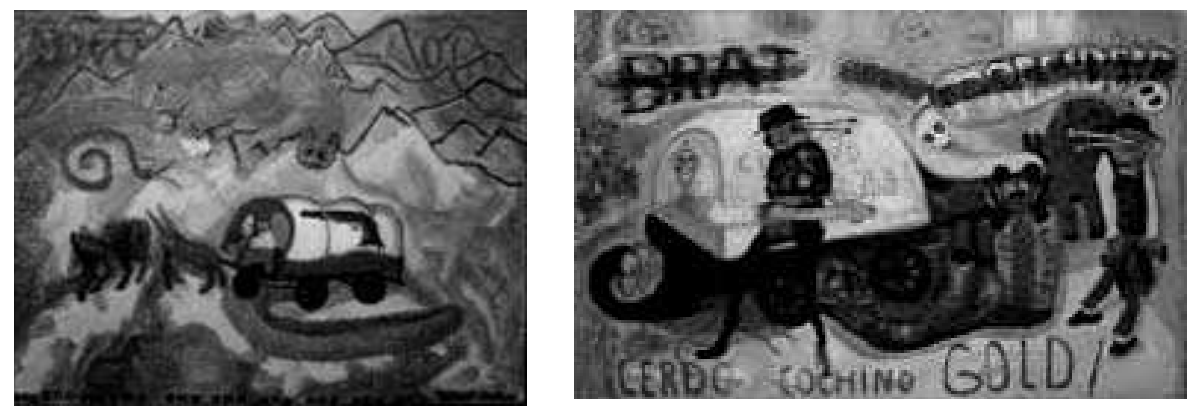

1. FRANCISCO PEINADO: "Valle minero" 2008-2009 óleo sobre lienzo 89,5 x 116,5 cm.

2. FRANCISCO PEINADO: "Cerdo cochino gold" 2008-2009 óleo sobre lienzo 200 x $300 \mathrm{~cm}$.

ca: pistolas y sombreros de cowboys, caravanas y diligencias con sus caballos, campamentos en un valle minero, una carreta atravesando un sendero en una escarpada montaña, tiendas de campaña, casa encantada o/y prostíbulo, calaveras, bandera, e interiores y paisajes típicos de este género cinematográfico popular; pleonasmo sometido al lenguaje y a la mirada expresionista con que nos tiene acostumbrado el artista, en una nueva vuelta de tuerca en su juego con los mitos más conocidos de ese imaginario cinematográfico estadounidense, que también es el nuestro. La anterior exposición que visité de este pintor -no sé si se corresponde cronológicamente con la última suya- estaba también marcada por la intertextualidad de uno de los mitos más populares de Hollywood: King Kong, el mito de la bestia y la bella.

Ahora, todas las obras de esta exposición están referidas a uno de los temas míticos más tratado por este género popular del western: la búsqueda del oro, que en la obra expuesta de dimensiones más amplia lleva el significativo título, escrito en el propio cuadro, Cerdo Cochino Gold, expresión de lenguaje híbrido, popular y despectiva, para aludir a la ambición de dinero que gobierna, dirige y domina, al parecer, nuestra sociedad y nuestras vidas, con lo que nos encontramos con un primer sentido con que encauzar nuestra visión de la exposición; además, la palabra oro aparece escrita reiteradamente en su colorido esencial en la mayoría de las obras expuestas.

Pero este tema dominante del western americano está alterado por la libertad de articulación y mezcla heterogénea de sus elementos, pues resulta que algunas veces, o bien la carreta está tirada por cerdos en vez de caballos, y en la lona que la cubre se puede ver la figura de Mickey Mouse junto al nombre escrito de nuestro presidente del gobierno, Zapatero, y un eslogan político, queremos oro, con una onomatopeya en consonancia más bien con el tebeo que con el comix ; o bien, otra carreta está tirada por escorpiones y escrito en la lona-pancarta el lema Darling Gold, aparte de otras alusiones escritas a este tema del oro como Gold Zapatero, I want 


\section{crítica de exposición}

3. FRANCISCO PEINADO: "Warning" 2009 óleo sobre cartón $81 \times 120 \mathrm{~cm}$.

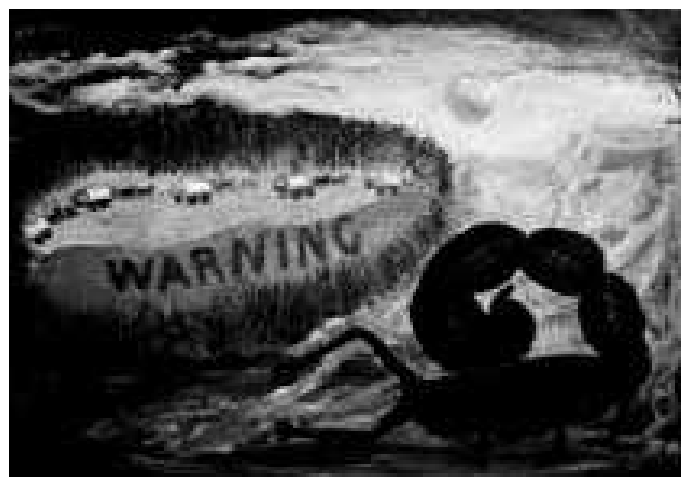

gold zapatero, Brat president, así como otra diligencia que lleva como referente pintado en su lona un gran revólver. Estas alteraciones deconstructivas del imaginario ficcional se revela en otra ocasión mediante la exposición de unas amenazadas carretas, en típica formación circular, que parecen se defienden -warning- de su enemigo, en este caso un enorme escorpión de color negro, entre otras perturbaciones y perífrasis de similar parecido, si bien el artista se ha cuidado mucho de incluir en esta sátira burlesca sobre nuestro imaginario occidental de pistoleros a los perdedores y víctimas de siempre: los valientes guerreros indios, quienes quedan un tanto al margen de la parodia, y que en todo caso están oportunamente representados en forma zoomórfica, unas veces como el mal -escorpión-, siguiendo en ello el juego paródico del propio imaginario occidental de imaginarlos como negros, salvajes y de peligrosa y mortal mordedura, -flechas-; otras, como un aparente y extraño animal que sale de entre las montañas con forma redondeada y alargada en figura de pluma color rosa, y en cuya cabeza unos sorprendidos y asombrados ojos contemplan a la carreta del revólver, juego paródico de nuevo sobre el fantasmático imaginario occidental de unos seres con un desmesurado y salvaje apetito sexual, -bicha rosada-; o en otras ocasiones vistos como la misma muerte canina, -calaveras.

En realidad, esta exposición de Francisco Peinado constituye en nuestra consideración particular un pastiche satírico y burlesco; o dicho de otra manera, el collage transtextual y paródico de variados géneros populares entronizados por los medios de comunicación de masas contemporáneos del cine y la televisión: dibujos animados y películas del oeste; así como también por el género popular más reciente de los carteles de comunicación de propaganda política, escrita en este caso, que el artista re-crea en un diálogo particular entre ellos dando forma así a un nuevo mundo fantástico con el que se rompe y subvierte doblemente la idea de unidad, coherencia o verosimilitud del discurso racional e incluso ficcional. Toda esta transestilización de géneros constituye el mundo imaginario que en esta ocasión el pintor 


\section{crítica de exposición}

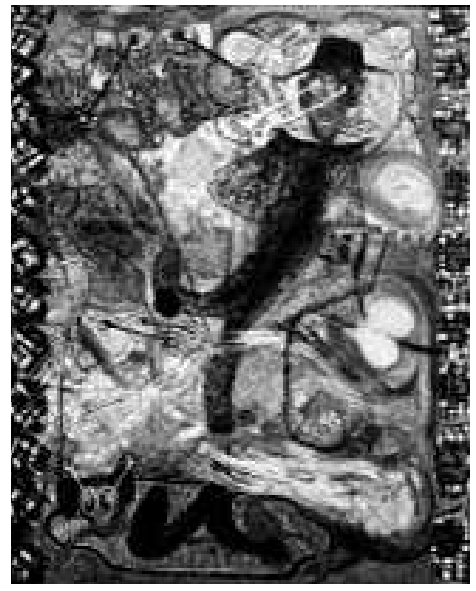

4. FRANCISCO PEINADO: "Johnny veneno" 2009 óleo sobre lienzo, $162 \times 130$ $\mathrm{cm}$.
Francisco Peinado nos muestra con su particular humor crítico a través de la imitación y transformación paródica de géneros populares y su sátira cómico-política.

Destacar, paralelamente, los diferentes, variados y significativos contrastes, como por ejemplo el pictórico entre la intensa gama cromática de colores marrones y negros utilizada para los interiores recargados de objetos y personajes, y el mucho más matizado colorido de los paisajes exteriores de una naturaleza radiante: amarillos, azules, tierra -rojo o carmín-, anaranjados, ocres o blancos entre otros; contraste comparable con otros temáticos que de nuevo podemos encontrar entre los exteriores, donde aparece reiterada una serpiente de sobresaliente lengua bífida, y los interiores, en los cuales los personajes o cowboys

aparecen representados con su reiterada mirada bifurcada de ojos desorbitantes en forma de resorte cómico. Antítesis otras veces conseguida a través del procedimiento textual del travestimiento, como sucede por ejemplo en el caso de los caballos, travestidos de cerdos -corceles yankees- y de escorpiones o alacranes -caballos salvajes-, siguiendo en todo ello la lógica semántico narrativa de los textos que venimos señalando. O bien la oposición entre la nocturna cena canibal y la diurna engañifa del hombre blanco. Y entre estas disparidades contrastivas, el elemento de burla asimismo insistente de los muñecos de la fantasía disney; aparte de otros diseminados animales con doble antena, como el más que llamativo de la cabeza del enorme pene-fusil en la obra primordial de esta exposición. Asimismo, otra característica importante de este lenguaje expresivo de Francisco Peinado se encuentra en la mirada pictórica de su fabulación, en la focalización expresionista en la que encuadra sus textos, en una nueva mezcla textual esta vez de diferentes y retorcidas perspectivas superpuestas.

Por otra parte, la des-figuración a las que somete a sus personajes, ya sea a través de la acción de un aparente baile en la cantina, en la que sobre el pistolero vestido de negro y sobre fondo oscuro destacan lúdicas y sensuales formas de tonos rosa y manjares de color rojo. Así, en la obra principal e hiperbólica que culmina esta exposición, podemos observar a un scheriff falocéntrico con su placa, y un sombrero donde casi apenas se puede apreciar el emblema nazi, enfrentándose a un pistolero con el enorme fusil- pene-rosa. En la misma obra, la formidable diligencia repre- 


\section{crítica de exposición}

senta en esta ocasión a la ley, palabra escrita repetidamente sobre la loneta, y en cuya parte trasera observamos la figura de una mujer asombrada o estupefacta (de qué) que mira el duelo y grita, o más bien lo contiene, en un claro juego intertextual con el conocido cuadro de Edvard Munch, y cuya silueta la recorre un trazo de color rosa; diligencia sostenida en esta ocasión por un extraño y monstruoso animal híbrido por cuya cola hendida y vertical eyacula una copiosa sustancia rosa. También podemos contemplar en esta obra las diferentes temáticas de los lemas, las calaveras y dibujos animados, y el juego asimismo intertextual de los diferentes estilos, procedimientos y técnicas pictóricas consumadas todas ellas en este texto límite.

Todo esto en el bien entendido sentido del más libre juego de la imaginación fenoménica y semiótica con la realidad y la ficción respectivamente, en la que desaparece cualquier atisbo de identidad estable o establecida, y su lugar lo ocupa una fantasía desbordada en su continua movilidad y transformabilidad de contrastes, cambios, diferencias y desviaciones del código recibido de sentido, ya sea en su modalidad real, ficcional o pictórica.

Si bien la asociación entre el oro y nuestra situación económica y política actual, en su dimensión global o geo-occidental, puede resultar evidente como una primera lectura literal, e incluso la semejanza paródica entre las caravanas del western en busca del oro y las caravanas electorales en busca del nuevo oro, el voto, parecen evidentes como decimos, mucho más interesante se nos aparece la combinación y mezcla heterogénea de las imágenes como sintaxis y semántica del lenguaje visual, donde la imaginación ocupa su verdadero lugar al presentarnos una realidad transformada y creada a base de la apropiación polifónica de registros estilísticos o retóricos, temático visuales, provenientes del mundo fantástico del cuento y del cine. No menos interesante resulta la combinación y mezcla heterogénea de la materialidad de los procedimientos pictóricos como constituyentes morfológicos de la expresión visual, donde la pintura está situada al mismo nivel textual que el componente anterior, en su representación de una figuración mediatizada por la apropiación de formantes materiales de diversos registros estilísticos y pictóricos provenientes del propio mundo de la historia de la pintura: expresionismo, figuración, abstracción, o técnicas de pinceladas puntillista o pintura plana entre otras manifestaciones, consiguiendo a través de estas diferentes texturas el volumen, profundidad y perspectiva sobre la pintura plana.

Si entramos ahora en el ámbito espacio-temporal de los textos de esta exposición, su diégesis, podemos obsevar la mezcla y convivencia de universos heterogéneos en su composición. Sobre el universo espacio-temporal dominante y básico de la narración, el western, se transponen y mezclan los elementos ficcionales del género de los dibujos animados con sus distintas temáticas por un lado, y elementos históricos pertenecientes al presente político por otro. De esta forma, en el espacio diegético de una obra se produce el anacronismo textual de unir y salpicar en una misma acción detalles estilísticos y temáticos pertenecientes a universos espacio- 


\section{crítica de exposición}

temporales diferentes. Así vemos como se introducen y reúnen en el mismo universo espacio temporal del cuadro universos espacio temporales de otros géneros, en un mestizaje de cowboys o caravanas del género del western americano con Mickey Mouse, los tres cerditos y Zapatero por ejemplo. Transformación pragmática o modificación de los elementos de la acción y de los objetos por una parte, y mezcla heterogénea de géneros por otra, que constituyen la técnica y estructura básica, así como la originalidad sobre la que se construye esta narración intertextual de Francisco Peinado, creando con ello, en consecuencia, un nuevo universo espacio-temporal inédito o fantástico donde reside en parte el asombro, la sorpresa -o sonrisa- que puede sentir el espectador. Al mismo tiempo, esta mezcla de espacios temporales pertenecientes a diferentes esferas genéricas de la ficción, conlleva la transposición de valores axiológicos de unos a otros universos. De esta manera Zapatero, o la política por ejemplo, sufre una desvalorización negativa a causa de estar integrado en el universo diegético espacio temporal de los dibujos animados y vaqueros del oeste, con lo que se produce también una sensación de burla o comicidad, rebajamiento percibido en forma de desmitificación en unos casos, o de crítica en otros, fácilmente reconocibles por el espectador.

Magnífica, por tanto, esta nueva propuesta intertextual y dialógica de Francisco Peinado, donde la imaginación, el humor o la burla y la mezcla de imágenes pertenecientes a universos diegéticos diferentes, están todas ellas unificadas en su pertenencia a un único universo hipertextual de la fantasía popular de narraciones, fábulas ficcionales y pictóricas, resueltas en la clave de una parodia satírica del imaginario ficcional de occidente; transtextualidad de la cual Francisco Peinado se apropia en un auténtico reto imaginativo de creación entre la pintura y los modernos medios tecnológicos masivos de creación de imagenes, situando con ello a la olvidada y marginada pintura, según algunos agotada y fuera de lugar en este fin de la modernidad, en un nuevo y destacado puesto en esta, como quiero llamarla, confusa etapa histórica de transición entre edades que nos ha tocado vivir; donde parece, paradójicamente, que los agotados por saturación son ahora aquellos medios que desplazaron en su día a la pintura, en una vuelta cómica de lo reprimido; al menos en obras de alta calidad como es ésta de Francisco Peinado según mi opinión, y otras obras de artistas extranjeros de la talla de Jonathan Meesl y Albert Oehlen, o nacionales como Curro González o Matías Sánchez. Exposición, finalmente, que hay que agradecer a la explendida sala, Galeria JM, y a su director Javier Marín, que nuevamente nos regala muestras de su buen hacer y coherencia estética de sus siempre arriesgadas propuestas artísticas. 